\title{
Citizen Behavior Model in Urban Farming Development
}

\author{
Abdullah \\ Universitas Muslim \\ Indonesia \\ Makassar, Indonesia
}

\author{
Nurlita Pertiwi \\ Universitas Negeri Makassar \\ Makassar, Indonesia
}

\author{
Faizal Amir \\ Universitas Negeri Makassar \\ Makassar, Indonesia
}

\author{
Sukrimin Sapareng \\ Universitas Andi Djemma \\ Palopo, Indonesia
}

\begin{abstract}
The study aims to investigate the characteristics of citizen behavior in the development of urban farming in the city of Makassar, South Sulawesi Province. The sample selection is using probability sampling of 300 respondents aged 18-60 years from various levels of education, gender, and social status. Questionnaire developed from six variables, namely: environmental knowledge, knowledge of urban farming, subjective norms, and motivation in development of urban farming, environmental attitudes, and behavioral development of urban farming. Research using structural equation modeling (SEM). The results showed that the knowledge of urban farming directly influences of citizen behavior of urban farming. If the citizen is high, the formation of behavioral development of urban farming will raise. Environmental knowledge, motivation, and subjective norms indirectly influence of citizen behavioral of urban farming through their environmental attitudes.
\end{abstract}

Keywords-component; formatting; style; styling

\section{INTRODUCTION}

Paradigm of city development or Eco City defines as the exploitation of potential ecological to construc facility under the present resource environment for the purpose of building an efficient, harmonious healthy and wealthy city [1]. The development concept which refers to the equilibration of environment and minimize the negative impact due to his construction. Makassar as a metropolitan city and the center of strategic areas in eastern part of Indonesia has increased the pace of infrastructure and construction accompanied by an increase in population. The condition will bring consequences of the occurrence of the excessive exploitation of the environment and urban socio-economic problems. The increasing number of residents requires balanced by the amount of the provision of food and nutrition, employment, housing, facilities, and infrastructure will give rise to problems of poverty and food insecurity of the city [2], [3].

One of the strategies being undertaken is the development system of urban farming. The system of urban farming is a form of revitalizing the agricultural sector while put back the sense of the importance of the agricultural sector and contextual proportionately in support of sustainable city development balance. Development of urban farming can impact favorably socio-economic community for life [4], [5] and the environmental balance of the city [3], [6].
However, the efforts of the urban development farming are a complex system with involving some components or elements which are integrated. It re requiring technical or technological approach as well as the approach of sociocultural. Theory of Planned Behavior explains that a particular behaviors occur due to the readiness to behave (behavioral intention) and determined by the attitude (behavioral attitude), subjective norm or social values that thrive in the community, as well as perceived behavioral control/self-efficacy-related personal analysis i.e. potential and resources [7]. The concept of the behavior theory can be used to explain the behavior of the development model of invalid construction of urban farming in Makassar.

\section{RESEARCH METHOD}

This research was conducted in Makassar and population is the community in the research area. The source of data is obtained by field observation and dissemination of the questionnaire to 300 respondents aged 18-60 years from the various levels of education, gender, and social status. The selection of respondents determined in probability sampling. This research analyze correlation predictive directly or indirectly between variables against the behavior of the development of urban agriculture. These research data were analyzed statistically descriptive and inferentially by using the analysis method of Structural Equation Modelling (SEM) based on software AMOS 22.

\section{RESULTS AND DISCUSSION}

The results showed in the table 1 that $68.30 \%$ respondent has high level of environmental knowledge. Furthermore, $96.00 \%$ of people have a high knowledge about urban farming. Therefore, the degree of knowledge, both from the aspect of facts, concepts or procedures about urban farming is relatively high and spread within the community of the city of Makassar. This characteristic of the knowledge level of the environment and urban farming which is high can be a driving force against the occurrence of behavior development of urban agriculture.

The subjective norms of citizen still low. It is shown that only $46 \%$ of respondent argue that the subjective norm is a important role as the driving force of the development of urban farming. Many indicators of subjective norm are belief in the role of the family, support from others, and support 
from the Government. Otherwise, there are $54 \%$ of community stated that subjective norms are not instrumental in increasing the development of urban farming in the city of Makassar.

TABLE I. CHARACTERISTICS OF BEHAVIORAL VARIABLES IN THE DEVELOPMENT OF URBAN FARMING

\begin{tabular}{|l|l|l|l|l|l|}
\hline \multirow{2}{*}{ Variables } & \multicolumn{5}{|c|}{ Category/Percentage } \\
\cline { 2 - 6 } & $\begin{array}{c}\text { Very } \\
\text { low }\end{array}$ & Low & $\begin{array}{c}\text { Modera } \\
\text { te }\end{array}$ & High & $\begin{array}{c}\text { Very } \\
\text { high }\end{array}$ \\
\hline Env. knowledge & - & 0.40 & 31.30 & 68.30 & - \\
$\begin{array}{l}\text { Knowledge of } \\
\text { urban farming }\end{array}$ & - & 0.00 & 4.00 & 96.00 & - \\
$\begin{array}{l}\text { Subjective norms } \\
\text { Motivation }\end{array}$ & 1.00 & 9.00 & 44.00 & 34.67 & 11.33 \\
$\begin{array}{l}\text { Attitude of the } \\
\text { environment } \\
\begin{array}{l}\text { Behavior of } \\
\text { urban farming }\end{array}\end{array}$ & 1.00 & 11.33 & 23.33 & 34.67 & 29.67 \\
\hline
\end{tabular}

The motivation of citizen of urban farming is high that as much as $64.34 \%$ of respondent have high motivation in developing of urban farming. Similarly, there are $62 \%$ of respondent have supported the development of urban farming. Nevertheless, the citizen behavior in the development of urban farming are still low, and only $34.30 \%$ of respondent had participated in the development of urban farming.

The test of hipothesis is based on the value of the Critical Ratio(C.R) in the Regression Weights: (Group number 1Default model) on the SEM analysis. The SEM analysis product in Table 2 indicates that there are six important direct causal relationships significantly (the value of C.R $\geq 1,967$ ).

TABLE II. RESUlts OF TESTING StATISTICAL HiPOTHESIS

\begin{tabular}{|c|c|c|c|c|c|}
\hline \multicolumn{3}{|c|}{ Research Hypoteis } & \multirow{2}{*}{$\begin{array}{r}\text { C.R. } \\
3.739\end{array}$} & \multirow{2}{*}{$\begin{array}{r}\mathbf{P} \\
* * *\end{array}$} & \multirow{2}{*}{\begin{tabular}{l}
\multicolumn{1}{c}{ Conclusion } \\
Direct \\
influence \\
significantly
\end{tabular}} \\
\hline $\begin{array}{l}\text { Knowledge of } \\
\text { urban farming }\end{array}$ & $<-$ & $\begin{array}{l}\text { Environmental } \\
\text { knowledge }\end{array}$ & & & \\
\hline Motivation & $<-$ & $\begin{array}{l}\text { Environmental } \\
\text { knowledge }\end{array}$ & .743 & .458 & $\begin{array}{l}\text { Direct effect } \\
\text { is not } \\
\text { significant }\end{array}$ \\
\hline Motivation & $<-$ & $\begin{array}{l}\text { Knowledge of } \\
\text { urban farming }\end{array}$ & 2.883 & .004 & $\begin{array}{l}\text { Direct } \\
\text { influence } \\
\text { significantly }\end{array}$ \\
\hline $\begin{array}{l}\text { Subjective } \\
\text { norms }\end{array}$ & $<-$ & $\begin{array}{l}\text { Knowledge of } \\
\text { urban farming }\end{array}$ & 2.960 & .003 & $\begin{array}{l}\text { Direct } \\
\text { influence } \\
\text { significantly }\end{array}$ \\
\hline $\begin{array}{l}\text { Subjective } \\
\text { norms }\end{array}$ & $<-$ & Motivation & 10.230 & $* * *$ & $\begin{array}{l}\text { Direct } \\
\text { influence } \\
\text { significantly }\end{array}$ \\
\hline $\begin{array}{l}\text { Attitude of } \\
\text { the } \\
\text { environment }\end{array}$ & $<-$ & Motivation & 5.758 & $* * *$ & $\begin{array}{l}\text { Direct } \\
\text { influence } \\
\text { significantly }\end{array}$ \\
\hline $\begin{array}{l}\text { Attitude of } \\
\text { the } \\
\text { environment }\end{array}$ & $<-$ & $\begin{array}{l}\text { Knowledge of } \\
\text { urban farming }\end{array}$ & .752 & .452 & $\begin{array}{l}\text { Direct effect } \\
\text { is not } \\
\text { significant }\end{array}$ \\
\hline
\end{tabular}

TABLE II, CONT.

\begin{tabular}{|c|c|c|c|c|c|}
\hline \multicolumn{3}{|c|}{ Research Hypoteis } & \multirow{2}{*}{$\begin{array}{r}\text { C.R. } \\
1.693\end{array}$} & \multirow{2}{*}{$\begin{array}{c}\mathbf{P} \\
.090\end{array}$} & \multirow{2}{*}{$\begin{array}{l}\text { Conclusion } \\
\text { Direct effect } \\
\text { is not } \\
\text { significant }\end{array}$} \\
\hline $\begin{array}{l}\text { Attitude of } \\
\text { the } \\
\text { environment }\end{array}$ & & $\begin{array}{l}\text { Environmental } \\
\text { knowledge }\end{array}$ & & & \\
\hline $\begin{array}{l}\text { Attitude of } \\
\text { the } \\
\text { environment }\end{array}$ & $<-$ & $\begin{array}{l}\text { Subjective } \\
\text { norms }\end{array}$ & 1.841 & .066 & $\begin{array}{l}\text { Direct effect } \\
\text { is not } \\
\text { significant }\end{array}$ \\
\hline $\begin{array}{l}\text { Behavior of } \\
\text { urban farming }\end{array}$ & $<-$ & $\begin{array}{l}\text { Knowledge of } \\
\text { urban farming }\end{array}$ & 4.229 & $* * *$ & $\begin{array}{l}\text { Direct } \\
\text { influence } \\
\text { significantly }\end{array}$ \\
\hline $\begin{array}{l}\text { Behavior of } \\
\text { urban farming }\end{array}$ & $<-$ & $\begin{array}{l}\text { Environmental } \\
\text { knowledge }\end{array}$ & .228 & .820 & $\begin{array}{l}\text { Direct effect } \\
\text { is not } \\
\text { significant }\end{array}$ \\
\hline $\begin{array}{l}\text { Behavior of } \\
\text { urban farming }\end{array}$ & $<-$ & $\begin{array}{l}\text { Attitude of the } \\
\text { environment }\end{array}$ & .421 & .674 & $\begin{array}{l}\text { Direct effect } \\
\text { is not } \\
\text { significant }\end{array}$ \\
\hline
\end{tabular}

TABLE III. INFLUENCE COEFFICIENT BETWEEN VARIABLES

\begin{tabular}{|c|c|c|c|c|c|}
\hline \multirow{2}{*}{\multicolumn{3}{|c|}{ Relationship between Variables }} & \multicolumn{3}{|c|}{ Coefficient Effect } \\
\hline & & & \multirow{2}{*}{$\begin{array}{c}\begin{array}{c}\text { Direct } \\
\text { Influen } \\
\text { ce }\end{array} \\
0.433\end{array}$} & \multirow{2}{*}{$\begin{array}{c}\begin{array}{c}\text { Influence } \\
\text { of } \\
\text { Indirect }\end{array} \\
-\end{array}$} & \multirow{2}{*}{$\begin{array}{c}\begin{array}{c}\text { Contri- } \\
\text { bution } \\
(\%)\end{array} \\
18.75\end{array}$} \\
\hline $\begin{array}{l}\text { Knowledge of } \\
\text { urban farming }\end{array}$ & $<-$ & $\begin{array}{l}\text { Environmental } \\
\text { knowledge }\end{array}$ & & & \\
\hline Motivation & & $\begin{array}{l}\text { Environmental } \\
\text { knowledge }\end{array}$ & 0.061 & 0.126 & 3.49 \\
\hline Motivation & & $\begin{array}{l}\text { Knowledge of } \\
\text { urban farming }\end{array}$ & 0.290 & - & 8.41 \\
\hline $\begin{array}{l}\text { Subjective } \\
\text { norms }\end{array}$ & $<-$ & $\begin{array}{l}\text { Knowledge of } \\
\text { urban farming }\end{array}$ & 0.187 & 0.220 & 16.56 \\
\hline $\begin{array}{l}\text { Subjective } \\
\text { norms }\end{array}$ & $<-$ & Motivation & 0.758 & - & 57.46 \\
\hline $\begin{array}{l}\text { Attitude of } \\
\text { the } \\
\text { environment }\end{array}$ & $<-$ & Motivation & 0.761 & 0.158 & 84.46 \\
\hline $\begin{array}{l}\text { Attitude of } \\
\text { the } \\
\text { environment }\end{array}$ & $<-$ & $\begin{array}{l}\text { Knowledge of } \\
\text { urban farming }\end{array}$ & 0.056 & 0.306 & 13.10 \\
\hline $\begin{array}{l}\text { Attitude of } \\
\text { the } \\
\text { environment }\end{array}$ & $<-$ & $\begin{array}{l}\text { Environmental } \\
\text { knowledge }\end{array}$ & 0.104 & 0.213 & 10.05 \\
\hline $\begin{array}{l}\text { Attitude of } \\
\text { the } \\
\text { environment }\end{array}$ & $<--$ & $\begin{array}{l}\text { Subjective } \\
\text { norms }\end{array}$ & 0.208 & - & 4.33 \\
\hline $\begin{array}{l}\text { Behavior of } \\
\text { urban farming }\end{array}$ & $<-$ & $\begin{array}{l}\text { Knowledge of } \\
\text { urban farming }\end{array}$ & 0.502 & 0.013 & 26.52 \\
\hline $\begin{array}{l}\text { Behavior of } \\
\text { urban farming }\end{array}$ & $<-$ & $\begin{array}{l}\text { Environmental } \\
\text { knowledge }\end{array}$ & 0.018 & 0.213 & 5.34 \\
\hline $\begin{array}{l}\text { Behavior of } \\
\text { urban farming }\end{array}$ & $<--$ & $\begin{array}{l}\text { Attitude of the } \\
\text { environment }\end{array}$ & 0.037 & - & 0.14 \\
\hline
\end{tabular}

Based on the relation in structural model (Table 3), it can be formulated that two substructure equations that describe the influences of exogenous variables toward to endogenous variables, as follows: 1 ) The attitude of green environment $=$ $0.761 *$ Motivation $+0.208 *$ subjective Norm + $0056 *$ Knowledge of urban farming+0.104*environmental knowledge+ $\zeta 1$; 2) behaviors of urban farming = $0.502 *$ knowledge of urban farming $+0.037 *$ The attitude of green environment $+0.018^{*}$ environmental knowledge $+\zeta 2$. 
The proposed model is the goodness of fit model and can be used to describe the relation between the influence of the variable constituent (Table 3).

The knowledge level about urban farming is influential directly significant to development attitude of urban farming with contribution $26.52 \%$.. It means that high or low the development attitude of urban farming can be influenced by the knowledge level of communities about urban farming. Therefore, to optimize the behavior of the development of urban farming needs to do the improvement of knowledge on urban farming for three aspects (facts, concepts, and procedures). These results are supported the theoretical framework of the model with environmental behavior responsible by the Hinnes [8].

Furthermore, regarding the environmental know-ledge, motivation development of urban farming and subjective norms indicate the indirect influence to the behavior of the development of urban farming. The attitude as intervening variables of the environment can have an intensity and positive or negative direction. The change of attitude toward a particular object can occur due to acquired additional information or knowledge about the object as well as the pressure from his social group. It emphasized that the attitude toward the behavior of the view of a person to have an assessment of the support or not support the behavior in question [9].

The environmental attitude become an intervening variables from the motivation of development the urban farming and subjective norms toward to the formation of behavior development of urban farming. The motivation of the development of urban farming causally become the prime mover factor being directly against It can be seen from its contributions of $84.46 \%$ attitude towards the environment. The motivation is internal and mental condition of the human form of existence of the desires, expectations, and needs that drive individuals to behave towards the object at hand [10].

\section{CONCLUSION}

The citizen have high category of knowledge about urban farming. The potential of agricultural knowledge becomes a driving force in the development of urban farming in a sustainable way. Knowledge of urban farming is an important role to increase the motivation of of urban farming, adherence to norms of behaviour and the formation of subjective, the development of urban farming.

Environmental attitudes become an intervening variable from the motivation of the development of urban farming and subjective norms toward to the formation of behavior development of urban farming. The increasing motivation, as well as optimization of the role of subjective norms in society, becomes an important variable to form a positive atti-tude towards the environment leading to improved behavior of the development of urban farming.

\section{References}

[1] M. Leźnicki and A. Lewandowska, 'Implementation of sustainable development on the example of the concept of eco-city', Ecol. Quest., vol. 19, pp. 91-96, 2014.

[2] A. Zezza and L. Tasciotti, 'Urban agriculture, poverty, and food security: empirical evidence from a sample of developing countries', Food Policy, vol. 35, no. 4, pp. 265-273, 2010.

[3] S. T. Lovell, "Multifunctional urban agriculture for sustainable land use planning in the United States', Sustainability, vol. 2, no. 8, pp. 2499$2522,2010$.

[4] A. Brock, 'Room to grow: Participatory landscapes and urban agriculture at NYU', New York New York Univ., 2008.

[5] K. Specht et al., 'Urban agriculture of the future: an overview of sustainability aspects of food production in and on buildings', Agric. Human Values, vol. 31, no. 1, pp. 33-51, 2014.

[6] H. Grover and S. Wahee, 'SUSTAINABILITY THROUGH URBAN FARMING: A CASE STUDY ON PRIYANKA AMAR SHAHWOMAN ECOPRENEUR', Int. J. Retail. Rural Bus. Perspect., vol. 2, no. 3, p. $600,2013$.

[7] A. N. Imran, N. P. Mulyadi, B. Rauf, and G. D. Dirawan, 'THE ENVIRONMENTAL BEHAVIOR OF COMMUNITY AT UPSTREAM MAROS CATCHMENT AREA', Man India, vol. 96, no. 9, pp. 3255-3266.

[8] H. R. Hungerford and T. L. Volk, 'Changing learner behavior through environmental education', J. Environ. Educ., vol. 21, no. 3, pp. 8-21, 1990.

[9] I. Ajzen, 'The theory of planned behaviour: reactions and reflections'. Taylor \& Francis, 2011.

[10] S. P. Robbins and T. A. Judge, 'Perilaku Organisasi Edisi 16', 2015. 